\title{
Need Analysis of Media Video Development for Character Education at Early Childhood Education in Padang
}

\author{
Abna Hidayati \\ Educational Technology \\ Universitas Negeri Padang \\ Padang, Indonesia \\ abnahidayati@gmail.com \\ Winanda Amilia \\ Educational Technology \\ Universitas Negeri Padang \\ Padang, Indonesia \\ winanda.amilia@gmail.com
}

\author{
Mutiara Felicita Amsal \\ Educational Technology \\ Universitas Negeri Padang \\ Padang, Indonesia \\ mutiaraamsal@gmail.com
}

\begin{abstract}
This study aims to identify initial needs for video development for the implementation of character education in early childhood. Needs analysis includes context analysis, analysis of learning environment and needs analysis. The method used in this research is quantitative with random sampling technique. The number of respondents is 30 teachers who teach in early childhood education in Padang City. Data collection techniques using questionnaires. Data is processed by using percentage technique.The results showed that from the context side related to the needs of the curriculum, $80 \%$ of children's learning needs assessed the importance of developing video for character learning. Furthermore, in terms of the learning environment as much as $\mathbf{7 5 \%}$ assess the use of video learning has not supported learning facilities. From the analysis side learners as much as $\mathbf{8 8 \%}$ assess the development of learning video needs to be done for the effectiveness of the implementation of character education in early childhood education.
\end{abstract}

Keywords-character values; religious; social; individual; persona; environment care; love the Fatherland.

\section{INTRODUCTION}

This study aims to identify initial needs for video development for the implementation of character education in early childhood. Character education is the real education through the understanding of concepts, applications and reflections and the regulation of the nature of self as intelligent and autonomous human capable of doing the best for themselves [1]. Education is a way of developing the potential possessed by humans. Education becomes a medium for the glorification of human beings with the development of capabilities possessed by humans, the more reflected the human glory and the essence of humanity. Education is very important in the process of developing various potentials owned by humans [2].

Needs analysis includes context analysis, analysis of learning environment and needs analysis. In the organization of education, teachers as the spearhead in the learning process need to pay attention intensively characteristics of learners in order to learning effectively. According to PP number 19 of 2005 described by Permendiknas no. 41 Year 2007 that the learning is done by running the Standard Process which requires that in the learning process, an educator must be able to pay attention to the characteristics of learners. Characteristics of learners for Smaldino (2008) consists of three things, the first, general characteristics consisting of age, gender, class and cultural and socioeconomic factors. Both specific competencies such as learning styles related to multiple intelligences, conceptual powers, informationprocessing habits, motivations and physiological factors [3]

The learning process that took place at the level of early childhood education has not been effective. In general, in early childhood educational institutions the ratio of educators and students is 1:30 children. Given the large number is believed not all children can be noticed by the teacher. Learners at the early childhood education have diverse behavior. Based on observations and interviews with several sources in the field found that the dominant teachers are less able to monitor children intensively in the process of education.

The results of teacher interviews in kindergarten AisyiahLubukLintah Padang mention that the kindergarten is less have a variety of learning media to optimize the learning process. In addition, the learning media used in the early childhood learning process is not owned by the school so it is quite difficult in the learning process. As is known that the use of media in the learning process proved to improve the learning 
process, especially in early childhood on character formation learning. Character building in early childhood becomes an important thing. Early childhood is a period of gold, so it is very important to form values of character at that age. The results of preliminary observations indicate that the dominant media learning for character education in kindergarten is still lacking. Generally the use of media is still focused on simple media and less attractive to children. In connection with this need to be developed learning video media for early childhood. In analyzing the video development, an initial analysis of the importance of early childhood learning is needed.

Character education in early childhood needs to be developed. There are several characteristics of developing character education for early childhood. Suyanto (2005) said that early childhood education is aimed to provide educational stimulation for the development of physical and spiritual aspects of the students to be ready to enter the next stage of education. Early childhood education is aimed at character building during the golden period of early childhood. Early childhood education is a priority because in the early stages of character building in early childhood [4].

The Association for Education and Communication Technology (AECT) defines the media that is all forms used for a process of information distribution. According to the National Education Association (NEA), defining as objects that can be manipulated, seen, heard, read or discussed along with instruments used properly in teaching and learning activities can affect the effectiveness of instructional programs [5].

The use of learning media has several functions, namely: (1) media can overcome the limitations of the learners experience, (2) the media can exceed classroom boundaries, (3) media allows for direct interaction between learners with their environment, (4) media results in uniformity of observations (6) the media generate new desires and interests, (7) the media generate motivation and stimulate the child to learn, and (8) the media provide an integral / comprehensive experience from the concrete to the abstract [6]

\section{METHOD}

The method in this research is quantitative. The population of the study were the teachers of early childhood education, with the samples taken randomly as many as 30 teachers teaching the PAUD in North Padang sub district which became the research location. Instrumentation of data collection using questionnaire. The next data is processed using SPSS.

\section{RESULT AND DISCUSSION}

In the early stages to develop a learning video about character education for learners a need analysis is made about the importance of character education.

\section{The needs of the curriculum in context}

In the context of the need for character education in early childhood has been formulated by the Ministry of National Education, especially in early childhood education. The values of character education according to the Team of the Directorate General of Early, Nonformal and Informal Education Ministry of National Education (2012: 5) can be embedded in early childhood (0-6 years), covering four aspects, namely: (1) Spiritual Aspects ; (2) Aspect Personal / personality; (3) Social Aspects; and (4) Environmental aspects. In this study formulated values that are important to be developed, which includes the value of Indonesian culture and culture of West Sumatra region. West Sumatra in particular is an area that strongly upholds the values of the characters. In relation to this a number of teachers agree on planting the value of the character is very important to be developed in early childhood education, because it is the identity of the local community [7].

Character education is an education that involves the cultivation of knowledge, love and cultivation of good behavior that becomes a pattern / habit. Character education can not be separated from the basic values that are considered good. In early childhood education the values are considered very important to be introduced and internalized into their behavior. In this case it is important, internalize the values of these characters to learners to be attached to the community.

The values of the characters developed include: love of God, honesty, discipline, tolerance and peace, confident, independent, help, cooperation and mutual cooperation, respect and courtesy, responsibility, hard work, leadership and justice, creative, humble, caring about the love environment of the nation and the homeland as well as a number of other values related to the character values of society in West Sumatera.

\section{Learning environment}

The learning environment is anything that is beyond the learner who is the primary support tool for character value development. Learning environment is very important for the implementation of character values. In this case if it is not supported by a positive environment, then the character values will be difficult to develop. The learning environment in this case is a means of supporting the implementation of character education such as school facilities, religious facilities and other supporters.

\section{Analysis of learners}

Student analysis is very important in the implementation of character education. In this case the developers of instructional video media need to consider the character education indicators for the students of early childhood education.

\section{TABLE I.}

CHARACTER

EDUCATION NEEDS ANALYSIS

\begin{tabular}{|l|l|l|}
\hline No & \multicolumn{1}{|c|}{ Indicator } & $\begin{array}{c}\text { Total } \\
\mathbf{\%}\end{array}$ \\
\hline 1 & The needs of curriculum in context & 80 \\
\hline 2 & Learning Environment & 75 \\
\hline 3 & Students & 88 \\
\hline
\end{tabular}

Based on the data obtained that in context as much as $80 \%$ or in the category of necessary development of learning video is important to optimize character education in Paud institutions considering that most children at an early age are more likely to choose interesting media for learning. Furthermore, as many as $75 \%$ of teachers considered that facilities support for the implementation of character education are in enough categories. This means that in this context Paud institutions still need to prepare fassility support to optimize the implementation of character education in schools. Furthermore, 
at the stage of analysis of learners the average assessment per indicator is $88 \%$ or are in either category. This means that the average student has been judged good to get character education in accordance with the development of the analysis.

The data were then analyzed by using SPSS analysis to find the effect of the three variables and found as follows:

TABLE II.

MODEL SUMMARY

\begin{tabular}{|c|c|c|c|c|c|c|c|c|c|}
\hline \multirow{2}{*}{ Model } & \multirow{2}{*}{$\overline{\mathrm{R}}$} & \multirow{2}{*}{$\begin{array}{c}\mathrm{R} \\
\text { Square }\end{array}$} & \multirow{2}{*}{\begin{tabular}{|l} 
Adjuste \\
$\mathrm{d} R$ \\
Square \\
\end{tabular}} & \multirow{2}{*}{$\begin{array}{c}\begin{array}{c}\text { Std. Error } \\
\text { of the } \\
\text { Estimate }\end{array} \\
\end{array}$} & \multicolumn{5}{|c|}{ Change Statistics } \\
\hline & & & & & $\begin{array}{l}\text { R Square } \\
\text { Change }\end{array}$ & $\mid \begin{array}{c}\mathrm{F} \\
\text { Change }\end{array}$ & dfl & $\mathrm{d} f 2$ & Sig. F Change \\
\hline &, $916^{\mathrm{a}}$ & 839 & 821 & 2,09416 & 839 & 45,251 & 3 & 26 &, 000 \\
\hline
\end{tabular}

Based on the data it is obtained that the influence of character context, learning environment and characteristics of learners to the formation of characters that is 0.916 or $91.6 \%$

TABLE III. ANOVA

\begin{tabular}{|l|l|l|l|l|c|c|}
\hline \multicolumn{1}{|c|}{ Model } & Sum of Squares & df & Mean Square & F & Sig. \\
\hline \multirow{2}{*}{1} & Regression & 595,343 & 3 & 198,448 & 45,251 &, $000 \mathrm{~b}$ \\
& Residual & 114,023 & 26 & 4,386 & & \\
& Total & 709,367 & 29 & & & \\
\hline
\end{tabular}

Based on the data, it is obtained information that the context of character education, environment and characteristics of learners significantly influence together for the character formation of learners.

Borg and Gall (1979: 607) suggests that, "Context evaluation involves the analysis of problems and needs in aspecific educational settings. A need is defined as a discrepancy between an existing condition and a desire condition ". So in this case the evaluation of the context involves the analysis of why one program is needed, what the program needs and the things related to the program to be run. Contextual evaluation also illustrates the program objectives that are not achieved from the existing needs [8]. Ornstein (1989: 261) states theoretically, context is a study of the environment in which the program runs. Stufflebeam (in Onstein 1989) states, context is the most fundamental [9]. This analysis is useful to provide a rationale for setting goals. Context analysis describes the relevant environment, relating to the description of the expected conditions or actual conditions occurring within the environment. Context analysis leads to undiscovered needs and missed opportunities and the diagnosis of reasons for unseen needs. Context analysis is a situation analysis: reading the reality in which individuals find themselves and judging that reality is related to what they want to do.
Furthermore, environmental analysis is an integral part in the development of learning videos, meaning that in this case it is necessary to consider that environmental support that influences the implementation of character education. Characters will not be formed if they are not supported by their surroundings.

Furthermore, in the final stages of analysis of learners is also a part that is not less important. Pearson (2017) argues that included in the learner analysis of learning styles that affect the way people choose to learn, the motivation to learn, that is related to their willingness and enthusiasm to learn, the environment of learners, that is related to environmental conditions that affect them in learning, and skills Learn to learn skills, which are related to what skills affect them as learners [10]. Furthermore, in the analysis of the problems discussed about the problems that occur and its relation to the development of material content.

\section{CONCLUSION}

Based on requirement analysis, it is found that the influence of character context, learning environment and characteristic of learners toward character formation is 0,916 or $91,6 \%$. This means that in this case the three variables that the context of the importance of character education, learning environment, and learners significantly influence the development of character-learning videos on early childhood education.

\section{References}

[1] A. Olim, "Mencari metode pendidikan karakter untuk PAUD: Belajar berbasis layanan (service learning)," in Proceedings of The 4th International Conference on Teacher Education, 2010, pp. 146-161.

[2] D. Suryana, "Pendidikan Anak Usia Dini: Teori dan Praktek Pembelajaran." Padang: UNP Press, 2013.

[3] S. E. Smaldino, D. L. Lowther, J. D. Russell, and C. Mims, "Instructional technology and media for learning," 2008.

[4] P. R. Indonesia, "Undang-undang Republik Indonesia nomor 20 tahun 2003 tentang system pendidikan nasional," 2003.

[5] H. Asnawir and M. B. Usman, "Media Pembelajaran," Jakarta CiputatPers, 2002.

[6] A. Sudrajat, "Media pembelajaran," dalam http//www. psbpsma. org/content/blog/media-pembelajaran diunduh tanggal 25 Februari 2009 pukul 11.40 WIB, 2008.

[7] D. P. P. Masyarakat and D. J. P. A. U. Dini, "Non formal dan Informal Kementerian Pendidikan dan Kebudayaan,” Petunjuk Tek. Pengajuan dan Pengeloolaan Penyelenggaraan Pendidik. Kecakapan Hidup Berorientasi Pemberdaya. Peremp., 2012.

[8] W. R. Borg, "GALL, Meredith Damien," Educ. Res. Introd. New York, London Longman, 1979.

[9] A. C. Ornstein and F.P.Hunkins, Curriculum: Foundations, principles, and issues. Pearson Higher Ed, 2017.

[10] J.A. Henderson, D. A. Kysar, and R. N. Pearson, The torts process. Wolters Kluwer Law \& Business, 2017. 